\title{
Phytomass and nutrient release in soybean cultivation systems under no-tillage
}

\author{
Andressa Selestina Dalla Côrt São Miguel(1), Leandro Pereira Pacheco(2), Ícaro Camargo de Carvalho(1), \\ Edicarlos Damacena de Souza ${ }^{(3)}$, Priscilla Barros Feitosa ${ }^{(1)}$ and Fabiano André Petter ${ }^{(4)}$
}

\begin{abstract}
(1)Universidade Federal de Mato Grosso, Campus Universitário de Rondonópolis, Avenida dos Estudantes, oㅡ 5.055, Sagrada Família, CEP 78735-901 Rondonópolis, MT, Brazil. E-mail: andressadallacort@hotmail.com, camargoicaro@gmail.com, feitosapb@gmail.com (2)Universidade Federal de Mato Grosso, Departamento de Engenharia Agrícola e Ambiental, Campus Universitário de Rondonópolis, Avenida dos Estudantes, no 5.055, Sagrada Família, CEP 78735-901 Rondonópolis, MT, Brazil. E-mail: leandroppacheco@gmail.com (3)Universidade Federal de Mato Grosso, Departamento de Zootecnia, Campus Universitário de Rondonópolis, Avenida dos Estudantes, no 5.055, Sagrada Família, CEP 78735-901 Rondonópolis, MT, Brazil. E-mail: edidamacena2000@yahoo.com.br (4)Universidade Federal de Mato Grosso, Departamento de Agronomia, Campus Universitário de Sinop, Avenida Alexandre Ferronato, no 1.200, Setor Industrial, CEP 78557-267 Sinop, MT, Brazil. E-mail: petter.fabiano@gmail.com
\end{abstract}

Abstract - The objective of this work was to evaluate the effect of phytomass accumulation, soil cover, and nutrient cycling promoted by cultivation systems with annual and cover crops on the grain yield of soybean sown in succession in the Cerrado, in the state of Mato Grosso, Brazil. The experiment was carried out in a randomized complete block design with nine cultivation systems and four replicates, in two crop seasons. In 2014/2015, forage grasses and legumes were evaluated, besides fallow treatments. In 2015/2016, forage and legume intercropped or not with corn or sunflower and fallow were assessed; the soybean crop was evaluated following cover crops. Phytomass, soil cover, and nutrient cycling provided by cultivation systems, as well as soybean mass and yield, were determined. Urochloa ruziziensis alone or intercropped, compared with the fallow systems, promotes significant increases in phytomass production, soil cover and nutrient cycling, with an increase in the grain yield of soybean planted in succession. $\mathrm{N}$ and $\mathrm{K}$ are the most accumulated nutrients in the aerial part of the cover crops and are released in larger quantities in the soil in the two years of evaluation. Crotalaria spectabilis promotes an increase in soybean yield in the 2015/2016 crop season, compared with U. ruziziensis, due to the synchronism between $\mathrm{N}$ release and uptake under no-tillage system.

Index terms: Crotalaria spectabilis, Glycine max, Pennisetum glaucum, Urochloa ruziziensis, cover crops, decomposition.

\section{Fitomassa e liberação de nutrientes em sistemas de cultivo de soja sob plantio direto}

Resumo - O objetivo deste trabalho foi avaliar o efeito do acúmulo de fitomassa, da cobertura do solo e da ciclagem de nutrientes promovidos por sistemas de cultivo com culturas anuais e de cobertura sobre o rendimento de grãos de soja semeada em sucessão, no Cerrado de Mato Grosso. O experimento foi conduzido em delineamento de blocos ao acaso, com nove sistemas de cultivo e quatro repetições, em duas safras. Em 2014/2015, foram avaliadas forrageiras gramíneas e leguminosas, além de tratamentos em pousio. Já em 2015/2016, avaliaram-se forrageiras e leguminosas consorciadas ou não com milho ou girassol e pousio; o plantio da soja foi avaliado após as culturas de cobertura. Foram determinados a fitomassa, a cobertura do solo e a ciclagem de nutrientes proporcionados pelos sistemas de cultivo, bem como a massa e o rendimento da soja. Urochloa ruziziensis solteira ou em consórcio, quando comparada aos sistemas em pousio, promove incrementos significativos na produção de fitomassa, na cobertura do solo e na ciclagem de nutrientes, com aumento no rendimento de grãos de soja em sucessão. $\mathrm{N}$ e K são os nutrientes mais acumulados na parte aérea das culturas de cobertura e são liberados em maior quantidade no solo, nos dois anos de avaliação. Crotalaria spectabilis promove aumento no rendimento de grãos de soja na safra 2015/2016, em comparação a $U$. ruziziensis, pelo sincronismo entre liberação e absorção de $\mathrm{N}$ sob plantio direto.

Termos para indexação: Crotalaria spectabilis, Glycine max, Pennisetum glaucum, Urochloa ruziziensis, culturas de cobertura, decomposição.

\section{Introduction}

The climate of the Cerrado in the state of Mato Grosso, Brazil, is characterized by high temperatures and humidity in the period from October to March (harvest) and by lower accumulations of rainfall, with a decrease in photoperiod, from April to September 
(Mendonça et al., 2015; Castro et al., 2017). The selection of species with fast establishment and growth, capable of accumulating high amounts of phytomass for soil cover and of cycling nutrients for later release to the successive crop, is fundamental for no-tillage systems under the edaphoclimatic conditions of the Cerrado (Crusciol et al., 2005; Pacheco et al., 2011).

The intercropping of annual grain crops, such as corn (Zea mays L.) and sunflower (Helianthus annuus L.), with cover crops, like grasses and legumes, is an alternative to significantly increase phytomass production and nutrient accumulation in no-tillage systems (Pereira et al., 2016; Chieza et al., 2017). Grasses as pearl millet [Pennisetum glaucum (L.) R.Br.], Urochloa ruziziensis (R.Germ. \& C.M.Evrard) Morrone \& Zuloaga (Syn. Brachiaria ruziziensis), and Urochloa brizantha (A.Rich.) R.D.Webster [Syn. Brachiaria brizantha (A.Rich.) Stapf] are species with fast establishment, high phytomass production (above $10.000 \mathrm{~kg} \mathrm{ha}^{-1}$ ), and that are known to promote nutrient cycling (Teixeira et al., 2012; Pereira et al., 2016). Legumes are also included in productive systems, alone or intercropped with grasses in the second crop, in order to increase the productivity of successive crops, mainly by nitrogen supply (Chieza et al., 2017).

Part of the nutritional demand of the successive crop can be met by the gradual release of nutrients during the phytomass decomposition of cover crops (Teixeira et al., 2012). However, nutrient absorption and accumulation capacity, phytomass recalcitrance, and speed of nutrient release to the soil are factors that must be taken into account for there to be a synchrony between the release of nutrients by the phytomass and their absorption by the culture of interest (Mendonça et al., 2015; Pereira et al., 2016). It should be highlighted that the results obtained for nutrient accumulation and release differ among regions due to varying edaphoclimatic conditions; specifically in the state of Mato Grosso, studies are still incipient in this area.

The objective of this work was to evaluate the effect of phytomass accumulation, soil cover, and nutrient cycling promoted by cultivation systems with annual and cover crops on the grain yield of soybean sown in succession in the Cerrado, in the state of Mato Grosso, Brazil.

\section{Materials and Methods}

The experiment was conducted during the 2014/2015 and 2015/2016 crop seasons (second and third year of cultivation), at the experimental station of one of the campuses of Universidade Federal de Mato Grosso, located in the municipality of Rondonópolis, in the state of Mato Grosso, Brazil $\left(16^{\circ} 27^{\prime} 41.75^{\prime \prime} \mathrm{S}\right.$, $54^{\circ} 34^{\prime} 52.55^{\prime \prime} \mathrm{W}$, at an altitude of $292 \mathrm{~m}$ ). The first crop season was not evaluated, since it was the year when the experiment was implemented. The soil of the area was classified as a Latossolo Vermelho distrófico (Santos et al., 2014), i.e., a Hapludox, with a flat relief. The climate is of the CwA type, according to Köppen's classification, characterized as altitude tropical warm and humid (Souza et al., 2013). Rainfall and maximum and minimum temperatures during the experimental period are shown in Figure 1.

The chemical characterization of the soil was performed on October 4, 2013, and is shown in Table 1. Liming was performed on October 8 of the same year, with $4,000 \mathrm{~kg} \mathrm{ha}^{-1}$ (Sousa \& Lobato, 2004) of limestone filler $(99.02 \%$ effective calcium carbonate equivalent), incorporated throughout the area by harrowing and leveling with a disc plough.

Soybean [Glycine max (L.) Merr.] was cultivated during the crop season, between October and February, in all systems in both crop years. After harvest, in the off-season, the following treatments (second crops) were established: cover and grain crops alone in 2014 and intercropped in 2015; and two fallow treatments for both years, one under no-tillage, with weeds naturally propagated and then desiccated for soybean sowing, and the other under conventional tillage, with soil rotation before soybean sowing (Table 2). In 2014/2015, forage grasses and legumes were evaluated; and, in 2015/2016, forage and legume plants intercropped or not with corn or sunflower. Different cover species were assessed each year, since a greater species diversification allows a greater accumulation of phytomass and nutrients in the system (Chieza et al., 2017). In the single cropping systems, cover and fallow crops were sown with a $0.45 \mathrm{~m}$ inter-row spacing, whereas, in the intercropping systems, the annual crops corn and sunflower were planted with $0.45 \mathrm{~m}$ spacing and the intercropped cover crops were sown between the furrows a week later. The experiment was conducted in a randomized complete block design, with 
nine cultivation systems (Table 2) and four replicates, in experimental units measuring $7 \times 9 \mathrm{~m}$.

In 2014/2015, the soybean crop was sown on 10/29/2014, using the ANTA 82 RR cultivar, with 25 seeds per meter and an inter-row spacing of $0.45 \mathrm{~m}$ in all cultivation systems; harvest was performed on $3 / 2 / 2015$. Then, the second crops were sown (Table 2). On $9 / 22 / 2015$, the crops were desiccated in all systems, except in those containing U. ruziziensis, which was desiccated 30 days before in the 2015/2016 crop season, in order to aid in the planting of the previously dried soybean. In 2015/2016, soybean was sown on $10 / 29 / 2015$, using the TMG 1175 RR cultivar, also with 25 seeds per meter and inter-row spacing of $0.45 \mathrm{~m}$ in all cropping systems; harvest was carried out on
$2 / 16 / 2016$. In both crop seasons, soybean was sown under no-tillage in all cropping systems; the exception was the fallow system under conventional tillage, where plots were harrowed and leveled using a disc plough 30 days before soybean sowing.

In both crop seasons, soybean was fertilized with $120 \mathrm{~kg} \mathrm{ha}^{-1} \mathrm{P}_{2} \mathrm{O}_{5}$ and $22 \mathrm{~kg} \mathrm{ha}^{-1} \mathrm{~N}$ via monoammonium phosphate in the sowing furrow, besides $100 \mathrm{~kg}$ ha $^{-1} \mathrm{~K}_{2} \mathrm{O}$ via potassium chloride, half applied by broadcasting at pre-sowing and the rest at the $\mathrm{V}_{4}$ phenological stage. Moreover, in all soybean sowings, seeds were inoculated with the Semia 5079 and Semia 5080 strains of Bradyrhizobium japonicum (Nitragin Cell Tech HC, Monsanto BioAg Offic, Buenos Aires, Argentina), at the dose of $150 \mathrm{~mL}$ of inoculant for

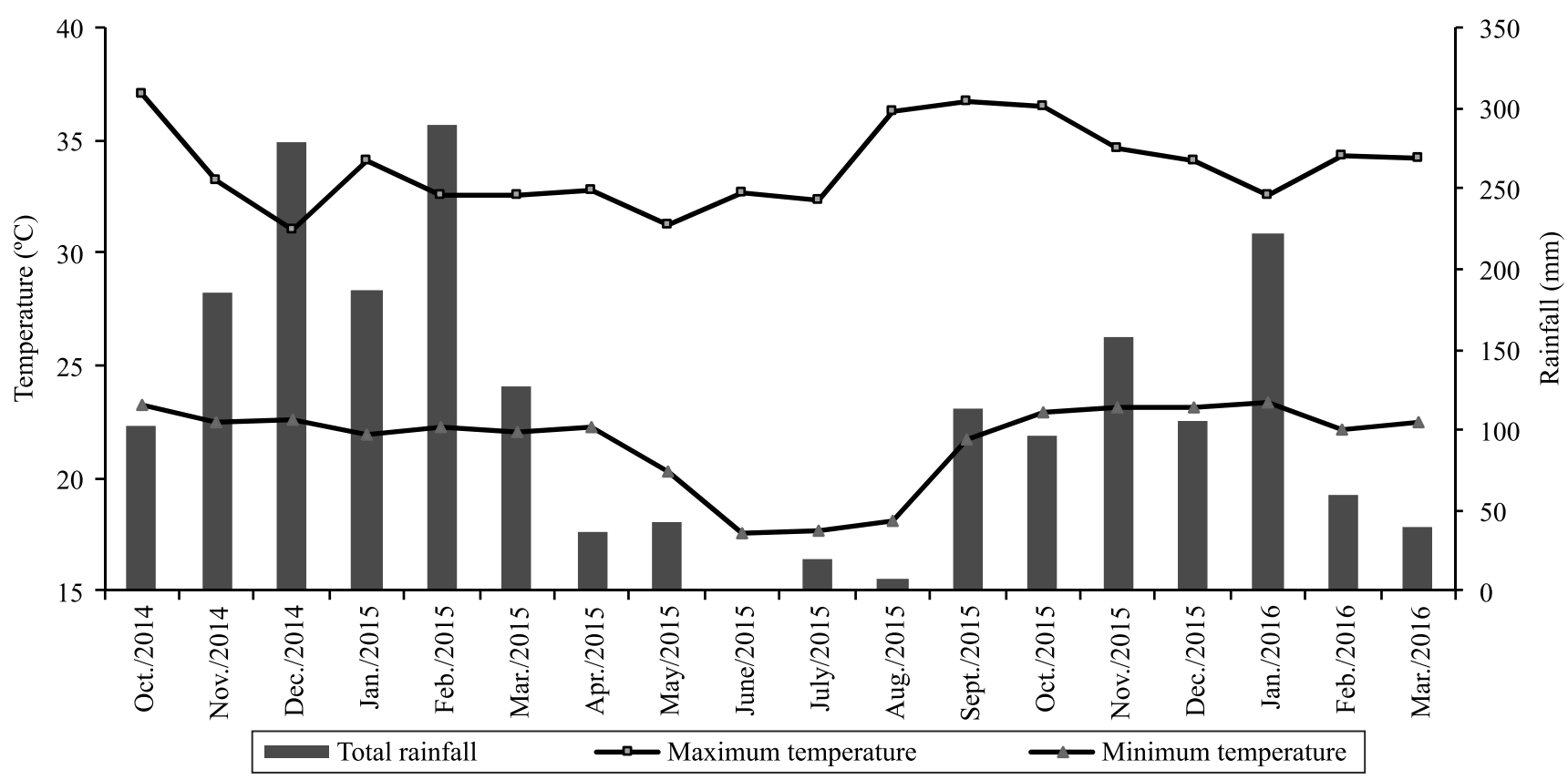

Figure 1. Monthly rainfall and minimum and maximum air temperatures during the experimental period, in the municipality of Rondonópolis, in the state of Mato Grosso, Brazil.

Table 1. Chemical and textural characterization of the Latossolo Vermelho distrófico (Hapludox) before the experiment was implemented in 2013 at the experimental area of Universidade Federal de Mato Grosso, located in Rondonópolis, in the state of Mato Grosso, Brazil ${ }^{(1)}$.

\begin{tabular}{|c|c|c|c|c|c|c|c|c|c|c|c|c|}
\hline \multirow{2}{*}{$\begin{array}{l}\text { Depth } \\
(\mathrm{m})\end{array}$} & $\mathrm{pH}$ & $\mathrm{P}$ & $\mathrm{K}$ & $\mathrm{Ca}$ & $\mathrm{Mg}$ & $\mathrm{H}+\mathrm{Al}$ & $\mathrm{T}$ & \multirow{2}{*}{$\begin{array}{c}\mathrm{V} \\
(\%)\end{array}$} & SOM & Sand & Silt & Clay \\
\hline & $\mathrm{CaCl}_{2}$ & \multicolumn{2}{|c|}{$----\left(\mathrm{mg} \mathrm{dm}^{-3}\right)^{----}$} & \multicolumn{4}{|c|}{ - } & & \multicolumn{4}{|c|}{ 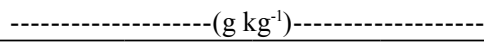 } \\
\hline $0.00-0.10$ & 4.1 & 5.4 & 55 & 0.5 & 0.2 & 6.8 & 7.6 & 11.0 & 17.6 & 450 & 125 & 425 \\
\hline $0.10-0.20$ & 4.0 & 1.4 & 49 & 0.2 & 0.2 & 7.2 & 7.6 & 5.6 & 19.9 & 500 & 100 & 400 \\
\hline $0.20-0.30$ & 4.1 & 0.2 & 31 & 0.3 & 0.1 & 6.2 & 6.7 & 7.2 & 13.7 & 500 & 100 & 400 \\
\hline
\end{tabular}

(1) , available phosphorus (Mehlich 1); $\mathrm{K}, \mathrm{Ca}$, and $\mathrm{M}$, exchangeable $\mathrm{K}^{+}, \mathrm{Ca}_{2}{ }^{+}$, and $\mathrm{Mg}^{+}$, respectively; $\mathrm{T}$, cation exchange capacity at $\mathrm{pH} 7.0$; $\mathrm{V}$, base saturation; and SOM, soil organic matter. 
each $50 \mathrm{~kg}$ of seeds. For grain cultures sown in the off-season, i.e., corn, cowpea [Vigna unguiculata (L.) Walp.], and sunflower, fertilizations followed the recommendations of Sousa \& Lobato (2004); however, no fertilizer was applied in plots with single cover crops.

The dry phytomass, soil cover, and nutrient release promoted by the cropping systems were determined in both evaluation years. Phytomass was assessed in October in both crop seasons, at $0,28,41,72,97$, and 118 days after desiccation (DAD) for soybean sown in 2014, and at 0, 14, 28, 68, 85, and 120 DAD in 2015. Soil cover was evaluated according to the methodology proposed by Crusciol et al. (2005), using two $50 \times 50 \mathrm{~cm}$ $\left(0.25 \mathrm{~m}^{2}\right)$ iron frames: one without and another with a string grid of 100 points in an area of $0.25 \mathrm{~m}^{2}$, with or without soil cover. After determining soil cover, the phytomass of the cover plant shoots and residues under the soil was collected and determined at two sampling points per plot. Afterwards, plant residues were subjected to drying in an oven at $60^{\circ} \mathrm{C}$, until constant weight, in order to obtain dried phytomass.

For soybean evaluations, the stand of plants per meter was determined during flowering, at three points per plot; six plants were then collected per plot for further analysis. Leaves were separated from stems and, after being measured, were dried in a forced-air circulation oven at $60^{\circ} \mathrm{C}$, until constant weight, in order to determine dry matter. Soybean and cover crop residues were ground in a Willey mill (2-mm mesh) in order to quantify nitrogen, phosphorus, potassium, calcium, and magnesium contents, following the methodology proposed by Nogueira et al. (2005). For soybean grain yield determination, two 2-m lines were collected; the results were expressed as $\mathrm{kg} \mathrm{ha}^{-1}$, and the samples were standardized to $13 \%$ humidity.

Data on phytomass decomposition after desiccation were adjusted to the following decreasing exponential mathematical model, described by Wieder \& Lang (1982): $\mathrm{Q}=\mathrm{Q}_{0} \exp (-\mathrm{kt})$ where $\mathrm{Q}$ is the amount $\left(\mathrm{kg} \mathrm{ha}^{-1}\right)$ of the nutrient existing in time $t$, in days; $Q_{o}$ is the fraction of potentially released nutrients $\left(\mathrm{kg} \mathrm{ha}^{-1}\right)$; and $\mathrm{k}$ is the nutrient release constant $\left(\mathrm{g} \mathrm{g}^{-1}\right)$. The $\mathrm{k}$-value was used to obtain the time required for half of the phytomass to decompose and for half of the nutrients to be released, i.e., the half-life time ( $\mathrm{T}^{1} / 2$ life) of each, using the formula proposed by Paul \& Clark (1989): $\mathrm{T}_{1 / 2 \text { life }}=0.693 / \mathrm{k}$.

Carbon was evaluated by the potassium dichromate method $\left(\mathrm{K}_{2} \mathrm{Cr}_{2} \mathrm{O}_{7}\right.$ at $\left.0.4 \mathrm{~N}\right)$, as described by Claessen (1997).

Cellulose and hemicellulose contents were also quantified using the indigestible neutral and acid detergent fiber evaluation methods, respectively, whereas lignin contents were determined through acid hydrolysis, according to Detmann et al. (2012).

The results were subjected to the analysis of variance, and, when significant, qualitative data were subjected to Scott-Knott's test, at 5\% probability, using the Sisvar, version 5.6, software (Ferreira, 2008). In

Table 2. Production systems sown in the 2014 and 2015 off-seasons after soybean (Glycine max) harvest in the 2013/2014 and 2014/2015 crop seasons, at the experimental area of Universidade Federal de Mato Grosso, located in Rondonópolis, in the state of Mato Grosso, Brazil.

\begin{tabular}{|c|c|c|}
\hline System & 2014 off-season & 2015 off-season \\
\hline $\mathrm{S}_{1}$ & Fallow under NT & Fallow under NT \\
\hline $\mathrm{S}_{2}$ & Fallow under CT & Fallow under CT \\
\hline $\mathrm{S}_{3}$ & $15 \mathrm{~kg} \mathrm{ha}^{-1}$ Crotalaria spectabilis & $15 \mathrm{~kg} \mathrm{ha}^{-1}$ Crotalaria spectabilis \\
\hline $\mathrm{S}_{4}$ & $17 \mathrm{~kg} \mathrm{ha}^{-1}$ Crotalaria breviflora & 60.000 corn (Zea mays) plants per hectare $+15 \mathrm{~kg} \mathrm{ha}^{-1}$ Crotalaria spectabilis \\
\hline $\mathrm{S}_{5}$ & $18 \mathrm{~kg} \mathrm{ha}^{-1}$ 'DR 8010' pearl millet (Pennisetum glaucum) & $30 \mathrm{~kg} \mathrm{ha}^{-1}$ 'ADR 300 ' pearl millet \\
\hline $\mathrm{S}_{6}$ & $15 \mathrm{~kg} \mathrm{ha}^{-1}$ Urochloa ruziziensis (CV of $60 \%$ ) & $15 \mathrm{~kg} \mathrm{ha}^{-1}$ Urochloa ruziziensis (CV of $60 \%$ ) \\
\hline $\mathrm{S}_{7}$ & $40 \mathrm{~kg} \mathrm{ha}^{-1}$ pigeon pea (Cajanus cajan) & $\begin{array}{c}55.000 \text { sunflower (Helianthus annuus) plants per hectare }+15 \mathrm{~kg} \mathrm{ha}^{-1} \\
\text { Urochloa ruziziensis (CV of } 60 \%)\end{array}$ \\
\hline $\mathrm{S}_{8}$ & $\begin{array}{c}8 \mathrm{~kg} \mathrm{ha}^{-1} \text { Stylosanthes capitata }+ \text { Stylosanthes } \\
\text { macrocephala }\end{array}$ & 160.000 cowpea (Vigna unguiculata) plants per hectare \\
\hline $\mathrm{S}_{9}$ & $15 \mathrm{~kg} \mathrm{ha}^{-1}$ 'Marandu' Urochloa brizantha (CV of $\left.60 \%\right)$ & 60.000 corn plants $+15 \mathrm{~kg} \mathrm{ha}^{-1}$ Urochloa ruziziensis (CV of $\left.60 \%\right)$ \\
\hline
\end{tabular}

${ }^{(1)} \mathrm{NT}$, no-tillage with weeds; CT, conventional tillage with harrow + leveling grid before soybean sowing; and CV, coefficient of variation. *Significant by the F-test, at $5 \%$ probability. 
addition, quantitative data referring to phytomass decomposition and nutrient release were adjusted in decreasing exponential equations, using the Sigma Plot, version 10.0, software (Systat Software Inc., San Jose, CA, USA).

\section{Results and Discussion}

The evaluated cropping systems significantly affected all analyzed variables. The one with Urochloa ruziziensis alone stood out for phytomass production after desiccation in both crop seasons, i.e., in 2014/2015 and 2015/2016 (Table 3). Pacheco et al. (2011) found similar values for this species in an experiment conducted in Rio Verde, in the state of Goiás, Brazil. It should be noted that this grass has the capacity to accumulate a high amount of phytomass, keeping soil covered during the off-season, after desiccation management, and after soybean cultivation in the crop season. This is interesting since phytomass maintains soil moisture, aiding in the growth of soybean cultivated in succession during crop seasons with prolonged water stresses or irregular rainfall distribution, as was the case in 2015/2016 (Figure 1).

Compared with $U$. ruziziensis alone, pigeon pea [Cajanus cajan (L.) Millsp.], pearl millet, U. brizantha in 2014, and corn + U. ruziziensis in 2015 presented intermediate results for phytomass production (Table 3). Pigeon pea showed a slower initial growth than the other species, but a significant regrowth rate after rainfall resumption, which resulted in a significant amount of phytomass at the time of desiccation (Table 3). This regrowth behavior, typical of legumes, was also observed in treatments including Crotalaria spectabilis Roth in 2014, pigeon pea in 2015, and cowpea. Similar results were reported by Pacheco et al. (2011) for pigeon pea, after the initial spring rains, in Rio Verde, in the state of Goiás, Brazil. However, the treatment fallow under no-tillage showed lower weed phytomass production for Digitaria horizontalis

Table 3. Phytomass production, soil cover, cellulose, hemicellulose, and lignin contents, $\mathrm{C} / \mathrm{N}$ ratio, and macronutrients of the annual and cover crops at the time of desiccation for soybean (Glycine max) sown in succession in the 2014/2015 and 2015/2016 crop seasons ${ }^{(1)}$.

\begin{tabular}{|c|c|c|c|c|c|c|c|c|c|c|c|}
\hline $\begin{array}{l}\text { Cultivation } \\
\text { system }\end{array}$ & $\begin{array}{c}\text { Phytomass } \\
\left(\mathrm{kg} \mathrm{ha}^{-1}\right)\end{array}$ & $\begin{array}{l}\text { Soil cover } \\
(\%)\end{array}$ & $\begin{array}{c}\text { Cellulose } \\
(\%)\end{array}$ & $\begin{array}{l}\text { Hemicel- } \\
\text { lulose (\%) }\end{array}$ & $\begin{array}{c}\text { Lignin } \\
(\%)\end{array}$ & $\begin{array}{l}\mathrm{C} / \mathrm{N} \\
\text { ratio }\end{array}$ & $\begin{array}{c}\mathrm{N} \\
\left(\mathrm{kg} \mathrm{ha}^{-1}\right)\end{array}$ & $\begin{array}{c}\mathrm{P} \\
\left(\mathrm{kg} \mathrm{ha}^{-1}\right)\end{array}$ & $\begin{array}{c}\mathrm{K} \\
\left(\mathrm{kg} \mathrm{ha}^{-1}\right)\end{array}$ & $\begin{array}{c}\mathrm{Ca} \\
\left(\mathrm{kg} \mathrm{ha}^{-1}\right)\end{array}$ & $\begin{array}{c}\mathrm{Mg} \\
\left(\mathrm{kg} \mathrm{ha}^{-1}\right)\end{array}$ \\
\hline & \multicolumn{11}{|c|}{ 2014/2015 crop season } \\
\hline $\mathrm{S}_{1}$, fallow under NT & $1.200 \mathrm{~d}$ & $41.66 \mathrm{~b}$ & $21.27 f$ & $33.65 \mathrm{a}$ & $8.59 \mathrm{~d}$ & $31.99 \mathrm{c}$ & $9.60 \mathrm{e}$ & $2.64 \mathrm{~g}$ & $21.60 \mathrm{~d}$ & $5.16 f$ & $3.00 \mathrm{e}$ \\
\hline $\mathrm{S}_{3}$, Crotalaria spectabilis & $3.158 \mathrm{c}$ & $33.33 b$ & $30.76 \mathrm{c}$ & $17.65 \mathrm{c}$ & $10.70 \mathrm{c}$ & $24.91 \mathrm{e}$ & $28.42 b$ & $8.90 \mathrm{c}$ & $31.58 \mathrm{c}$ & $15.71 \mathrm{e}$ & $7.26 \mathrm{~d}$ \\
\hline $\mathrm{S}_{4}$, Crotalaria breviflora & $2.236 \mathrm{c}$ & $24.99 b$ & $27.80 \mathrm{~d}$ & $13.48 \mathrm{e}$ & $11.94 b$ & $32.76 \mathrm{c}$ & $15.65 \mathrm{~d}$ & $4.68 \mathrm{f}$ & $8.94 \mathrm{e}$ & $12.52 \mathrm{e}$ & $4.25 \mathrm{e}$ \\
\hline $\mathrm{S}_{5}$, pearl millet ( $P$. glaucum) & $4.410 \mathrm{~b}$ & $33.33 b$ & $43.89 a$ & $23.54 b$ & $7.94 \mathrm{~d}$ & $54.88 \mathrm{a}$ & $22.05 \mathrm{c}$ & $7.86 \mathrm{~d}$ & $34.80 \mathrm{c}$ & $15.43 \mathrm{e}$ & $9.70 \mathrm{c}$ \\
\hline $\mathrm{S}_{6}$, Urochloa ruziziensis & $7.400 \mathrm{a}$ & $100.00 \mathrm{a}$ & $14.60 \mathrm{~g}$ & $15.80 \mathrm{~d}$ & $4.86 \mathrm{e}$ & $46.07 b$ & $44.40 \mathrm{a}$ & $15.65 \mathrm{a}$ & $103.60 \mathrm{a}$ & $32.09 \mathrm{a}$ & $22.94 a$ \\
\hline $\mathrm{S}_{7}$, pigeon pea (C. cajan) & $4.648 b$ & $55.55 \mathrm{~b}$ & $25.91 \mathrm{e}$ & $18.42 \mathrm{c}$ & $18.47 \mathrm{a}$ & $28.57 \mathrm{~d}$ & $41.82 \mathrm{a}$ & $9.71 \mathrm{~b}$ & $27.88 \mathrm{c}$ & $27.02 b$ & $9.14 \mathrm{c}$ \\
\hline $\mathrm{S}_{8}$, Stylosanthes $\mathrm{sp}$ & $2.896 \mathrm{c}$ & $44.44 b$ & $35.43 b$ & $13.55 \mathrm{e}$ & $2.54 \mathrm{~g}$ & $25.84 \mathrm{e}$ & $23.16 \mathrm{c}$ & $5.59 \mathrm{~d}$ & $23.16 \mathrm{~d}$ & $18.53 \mathrm{~d}$ & $7.23 \mathrm{~d}$ \\
\hline $\mathrm{S}_{9}$, Urochloa brizantha & $4.610 \mathrm{~b}$ & $83.33 \mathrm{a}$ & $27.47 \mathrm{~d}$ & $18.65 \mathrm{c}$ & $3.71 \mathrm{f}$ & $27.75 \mathrm{~d}$ & $41.48 \mathrm{a}$ & $10.36 \mathrm{a}$ & $55.31 \mathrm{~b}$ & $23.04 \mathrm{c}$ & $15.21 \mathrm{~b}$ \\
\hline \multirow[t]{2}{*}{ Coefficient of variation (\%) } & 15.63 & 31.73 & 3.14 & 4.72 & 7.57 & 3.91 & 17.61 & 8.20 & 18.18 & 14.12 & 18.54 \\
\hline & \multicolumn{11}{|c|}{ 2015/2016 crop season } \\
\hline $\mathrm{S}_{1}$, fallow under NT & $2.675 \mathrm{e}$ & $65.27 \mathrm{c}$ & $42.07 \mathrm{~b}$ & $23.67 \mathrm{c}$ & $12.26 \mathrm{~b}$ & $13.63 \mathrm{~d}$ & $54.30 \mathrm{e}$ & $3.80 \mathrm{e}$ & $22.64 \mathrm{e}$ & $8.55 \mathrm{~g}$ & $11.23 \mathrm{e}$ \\
\hline $\mathrm{S}_{3}$, Crotalaria spectabilis & $3.400 \mathrm{e}$ & $41.66 \mathrm{~d}$ & $41.46 b$ & $19.06 \mathrm{e}$ & $8.60 \mathrm{~d}$ & $17.38 \mathrm{c}$ & $53.38 \mathrm{e}$ & $6.58 \mathrm{~d}$ & $18.63 \mathrm{e}$ & $13.60 \mathrm{e}$ & $14.28 \mathrm{~d}$ \\
\hline $\mathrm{S}_{4}$, corn $+C$. spectabilis & $4.447 \mathrm{~d}$ & $58.32 \mathrm{c}$ & $48.54 \mathrm{a}$ & $22.59 \mathrm{c}$ & $6.42 \mathrm{e}$ & $16.75 \mathrm{c}$ & $76.48 \mathrm{~d}$ & $8.93 \mathrm{c}$ & $58.69 \mathrm{~b}$ & $25.75 d$ & $19.48 \mathrm{c}$ \\
\hline $\mathrm{S}_{5}$, pearl millet & $6.462 b$ & $84.71 \mathrm{~b}$ & $41.32 b$ & $27.25 b$ & $14.32 \mathrm{a}$ & $20.58 b$ & $95.64 \mathrm{c}$ & $6.91 \mathrm{~d}$ & $34.89 \mathrm{~d}$ & $36.93 b$ & $20.68 \mathrm{c}$ \\
\hline $\mathrm{S}_{6}$, U. ruziziensis & $8.071 \mathrm{a}$ & $100 \mathrm{a}$ & $39.52 \mathrm{c}$ & $30.67 \mathrm{a}$ & $3.47 \mathrm{f}$ & $24.53 \mathrm{a}$ & $93.62 \mathrm{c}$ & $17.59 \mathrm{a}$ & $45.67 \mathrm{c}$ & $46 \mathrm{a}$ & $34.70 \mathrm{a}$ \\
\hline $\mathrm{S}_{7}$, sunflower $+U$. ruziziensis & $5.092 \mathrm{c}$ & $84.71 \mathrm{~b}$ & $39.71 \mathrm{c}$ & $31.71 \mathrm{a}$ & $7.24 \mathrm{e}$ & $11.97 \mathrm{e}$ & $122.73 b$ & $12.48 \mathrm{~b}$ & $73.33 \mathrm{a}$ & $11.20 \mathrm{f}$ & $19.35 \mathrm{c}$ \\
\hline $\mathrm{S}_{8}$, cowpea $(V$. unguiculata $)$ & $2.478 \mathrm{e}$ & $38.88 \mathrm{~d}$ & $48.73 \mathrm{a}$ & $19.57 \mathrm{e}$ & $10.83 \mathrm{c}$ & $16.79 \mathrm{c}$ & $39.90 \mathrm{f}$ & $5.94 \mathrm{~d}$ & $32.54 \mathrm{~d}$ & $4.76 \mathrm{~h}$ & $9.41 \mathrm{e}$ \\
\hline $\mathrm{S}_{9}$, corn + U.ruziziensis & $6.213 b$ & $83.32 b$ & $30.60 \mathrm{~d}$ & $20.60 \mathrm{~d}$ & $6.64 \mathrm{e}$ & $11.99 \mathrm{e}$ & $156.58 \mathrm{a}$ & $9.94 \mathrm{c}$ & $18.64 \mathrm{e}$ & $34.79 \mathrm{c}$ & $27.96 \mathrm{~b}$ \\
\hline Coefficient of variation (\%) & 24.48 & 13.74 & 1.80 & 3.43 & 9.98 & 6.69 & 10.10 & 13.56 & 12.50 & 5.93 & 12.37 \\
\hline
\end{tabular}


Willd., Digitaria insularis (L.) Fedde, Porophyllum ruderale (Jacq.) Cass., and Tridax procumbens L., in both crop seasons, indicating that it was not an efficient management to be adopted (Table 3).

As for soil cover, $U$. ruziziensis and $U$. brizantha alone stood out in 2014 (Table 3). Similar results were obtained by Pacheco et al. (2008), who found $100 \%$ soil cover by grasses from the Urochloa genus in four evaluation periods, in Rio Verde, in the state of Goiás, Brazil. In the present study, compared with grasses, legumes provided lower soil cover at the time of desiccation, in both crop seasons (Table 3).

As for phytomass decomposition on soil surface, the lowest values were found for pearl millet and corn + C. spectabilis, as indicated by their longer half-life times in 2014 and 2015, respectively (Figure 2 A and B). It should also be pointed out that these two grasses have high tissue recalcitrance due to their $\mathrm{C} / \mathrm{N}$ ratios (Table 3).

Although C. spectabilis is a legume, its phytomass presented significant recalcitrance under soil surface, because it has a high lignin content in relation to the evaluated grasses (Table 3). The aromatic conformation of lignin molecules makes it difficult for them to be degraded by the enzymatic activity of microorganisms, raising the $\mathrm{C} / \mathrm{N}$ ratio of plant materials, as described by Carvalho et al. (2008). In studies conducted in the Cerrado of Planaltina, in Distrito Federal, Brazil, Carvalho et al. (2015) correlated the 213-day cycling time of Crotalaria juncea $\mathrm{L}$. straw with its $\mathrm{C} / \mathrm{N}$ ratio and the recalcitrance of lignin molecules.

The cropping systems affected macronutrient accumulation at the time of desiccation, and the one with $U$. ruziziensis alone stood out in both crop years (Table 3). This species presented the greatest amounts of most macronutrients, except of $\mathrm{N}$ and $\mathrm{K}$, which were accumulated in larger quantities by corn $+U$. ruziziensis and sunflower + U. ruziziensis, respectively, in 2015. These significant increases in $\mathrm{N}$ and $\mathrm{K}$, in this year, are due to the phytomass of corn and sunflower, respectively, since these nutrients are the most extracted by these crops according to Castro et al. (2005) and Sá et al. (2013); this enhances the importance of species diversification for no-tillage cultivation systems. The high accumulation of nutrients by $U$. ruziziensis was attributed to its significant phytomass production. Castro et al. (2017) highlighted that this species has an aggressive and comprehensive root system, which allows it to absorb nutrients from the deepest layers
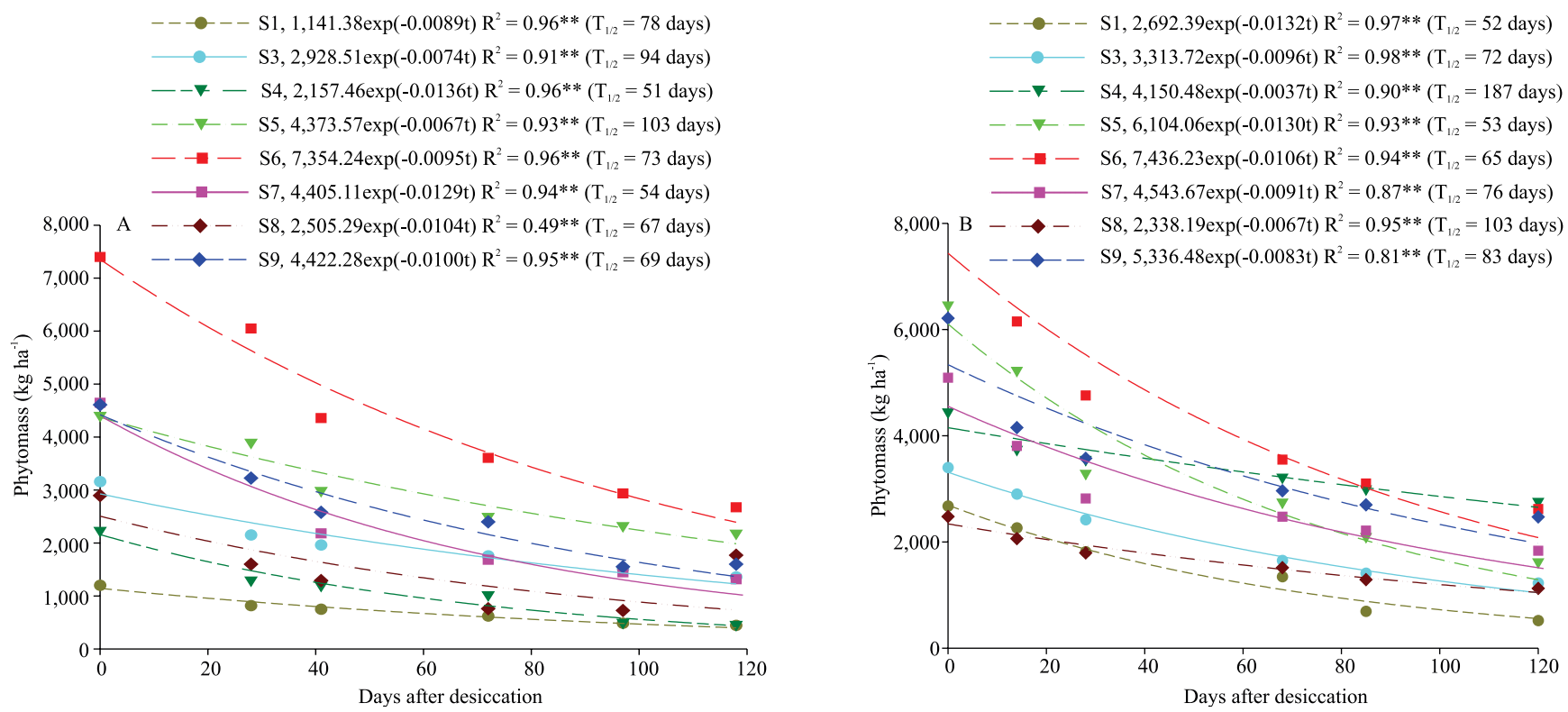

Figure 2. Remaining phytomass and half-life time ( $T_{1 / 2}$ ) of cover crops in the 2014/2015 (A) and 2015/2016 (B) crop seasons. Cultivation systems: S1, fallow under no-tillage; S3, Crotalaria spectabilis; S4, Crotalaria breviflora; S5, pearl millet (Pennisetum glaucum); S6, Urochloa ruziziensis; S7, pigeon pea (Cajanus cajan); S8, Stylosanthes sp.; and S9, Urochloa brizantha. NT, no-tillage. 
of the soil profile and to release them during the decomposition process.

The significant amount of $\mathrm{N}$ accumulated by pigeon pea, U. brizantha, and corn $+U$. ruziziensis is due to the high quantities of phytomass produced and to its $\mathrm{N}$ contents. Moreover, pigeon pea can promote the insertion of $\mathrm{N}$ into the system through biological fixation. Rufini et al. (2016) reported that this species is able to establish a symbiotic association with Bradyrhizobium and to supply up to $90 \%$ of the N used for its own growth and development.

The lower accumulation of $\mathrm{N}$ by the other leguminous species, such as Crotalaria, Stylosanthes and cowpea, was explained by their lower phytomass production. Stylosanthes showed the lowest accumulation of this nutrient, which was attributed to the species slow initial growth, as already observed by Andrade et al. (2010), which disfavors the production of phytomass and $\mathrm{N}$ accumulation.

The greatest accumulation of $\mathrm{K}$ in the sunflower $+U$. ruziziensis intercrop is an indicative that this nutrient is highly extracted from the soil by sunflowers and is little exported by grains, as already reported by Silva et al. (2015). According to Castro et al. (2005), sunflowers are able to absorb large amounts of this nutrient because of the greater volume of soil explored by their roots and most of the $\mathrm{K}$ accumulated by the plant remains in the shoot for later release to the soil. The intercrop with $U$. ruziziensis presented significant phytomass accumulation starting at sunflower senescence, as well as high regrowth capacity after the resumption of summer rains.

The macronutrients $\mathrm{N}, \mathrm{P}, \mathrm{Ca}$, and $\mathrm{Mg}$ presented similar half-life times in the cropping systems; the exception was $\mathrm{K}$, which showed a rapid initial release (Figures 3 and 4). The system with pearl millet had the greatest half-life times for most nutrients, especially $\mathrm{N}$, in both crop seasons. This can be explained by the $14 \%$ lignin contents and 17:1 C/ $\mathrm{N}$ ratio of the species (Table 3), which showed higher recalcitrance to the decomposition process.

Crotalaria spectabilis and Stylosanthes in the 2014/2015 crop season, as well as U. ruziziensis alone or intercropped with corn or sunflower in 2015/2016, presented mean half-life time of 30 days for $\mathrm{P}$ (Figures 3 and $4 \mathrm{~B}$ ), which is a cell constituent structurally connected to protein molecules and to compounds linked to energy transport (Mendonça et al., 2015). The rapid release of $\mathrm{P}$ by $U$.ruziziensis was also verified by Pacheco et al. (2011). According to these authors, this grass has a high regrowth capacity with initial summer rains and, therefore, has younger and less lignified tissues with low $\mathrm{C} / \mathrm{N}$ ratios, as observed in the present study (Table 3 ).

$\mathrm{K}$ showed a mean half-life time of 25 days in all systems and was the nutrient with the highest release rate (Figures 3 and $4 \mathrm{C}$ ). The treatments that stood out were fallow under no-tillage and sunflower + $U$. ruziziensis, with a half-life time of eight and five days, respectively. $\mathrm{K}$ was rapidly released by the intercrop due to the high concentration of this nutrient in sunflower leaves, and by U. ruziziensis tissues to the soil due to the lower $\mathrm{C} / \mathrm{N}$ ratio of the species, mainly in the initial phase of soybean establishment. Mendonça et al. (2015) also observed an accelerated release of $\mathrm{K}$ from phytomass to the soil, especially up to 30 days.

$\mathrm{Ca}$ and $\mathrm{Mg}$ were released similarly in all treatments, except in U. ruziziensis and corn $+U$. ruziziensis in the 2015/2016 crop season, which presented a halflife time close to 20 days each (Figures 3 and $4 \mathrm{D}$ and E). According to Mendonça et al. (2015), since these nutrients are part of structural compounds and soluble molecules, they were released rapidly because of the degradation after desiccation. The faster release of $\mathrm{Ca}$ in some treatments, such as that with $U$. ruziziensis alone, occurred because several plants were already dehydrated during desiccation due to the dry period in the off-season, which may have affected the obtained results.

In the 2015/2016 crop season, there were greater nutrient accumulations in the phytomass of soybean planted in succession in systems with annual and cover crops under no-tillage (Figure 5). More diversified systems may favor microbiological activity and the interaction between Bradyrhizobium japonicum and soybean root nodules for $\mathrm{N}$ fixation (Silva et al., 2011), as well as the proliferation of essential nutrientsolubilizing microorganisms in the soil solution during soybean development (Pacheco et al., 2017).

There was no effect of cropping systems on the grain yield of soybean sown in succession to annual and cover crops in the 2014/2015 crop season (Table 4). In 2015/2016, systems using intercropped and single notillage crops in the off-season, especially the one with C. spectabilis alone, differed significantly regarding soybean yield. The difference in grain yield between

Pesq. agropec. bras., Brasília, v.53, n.10, p.1119-1131, Oct. 2018 DOI: 10.1590/S0100-204X2018001000005 

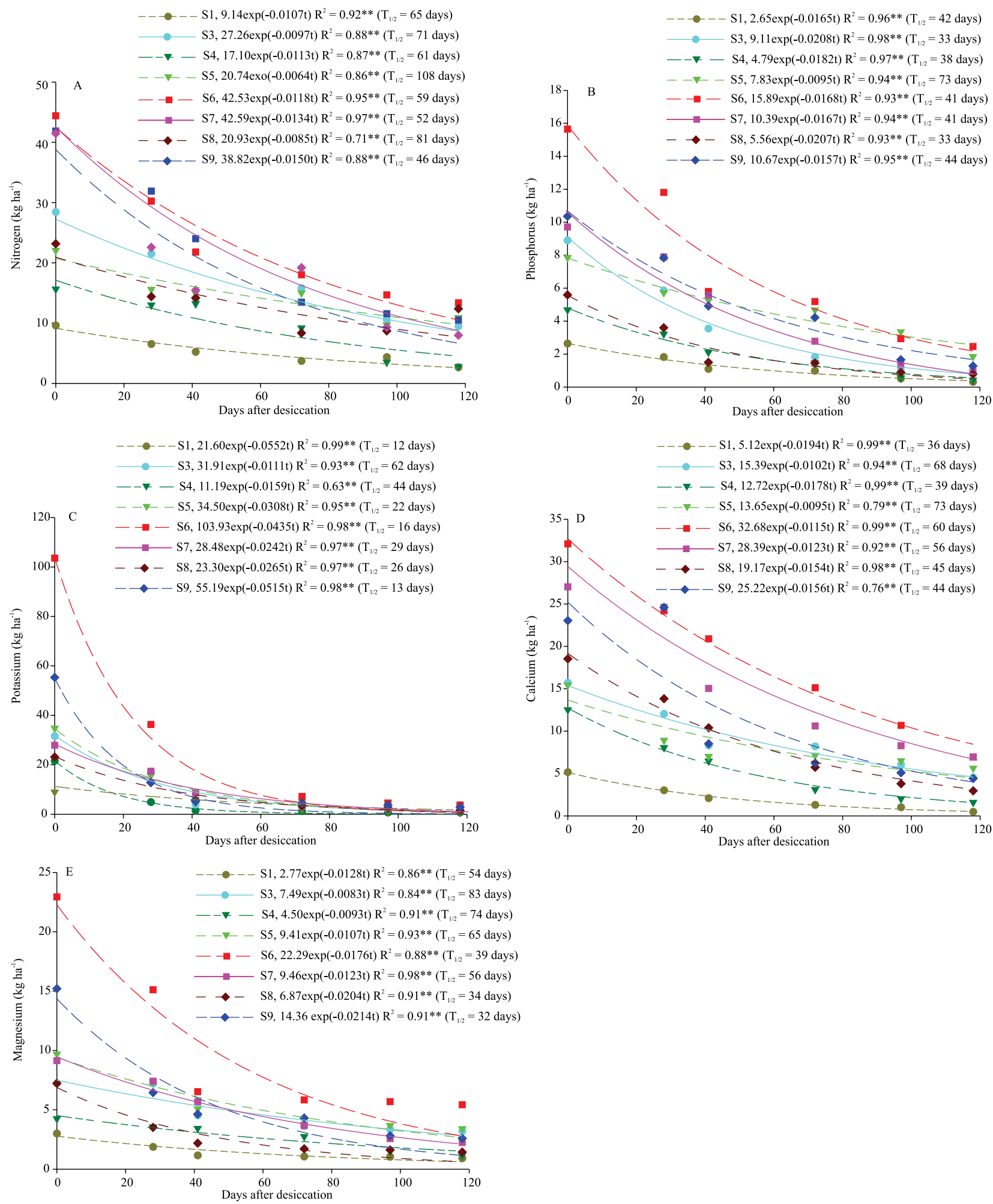

Figure 3. Release of nitrogen (A), phosphorus (B), potassium (C), calcium (D), and magnesium (E) by cover crops in the 2014/2015 crop season, in the municipality of Rondonópolis, in the state of Mato Grosso, Brazil. Cultivation systems: S1, fallow under no-tillage; S3, Crotalaria spectabilis; S4, Crotalaria breviflora; S5, pearl millet (Pennisetum glaucum); S6, Urochloa ruziziensis; S7, pigeon pea (Cajanus cajan); S8, Stylosanthes sp.; and S9, Urochloa brizantha. NT, no-tillage; and $\mathrm{T}_{1 / 2}$, half-life time. 

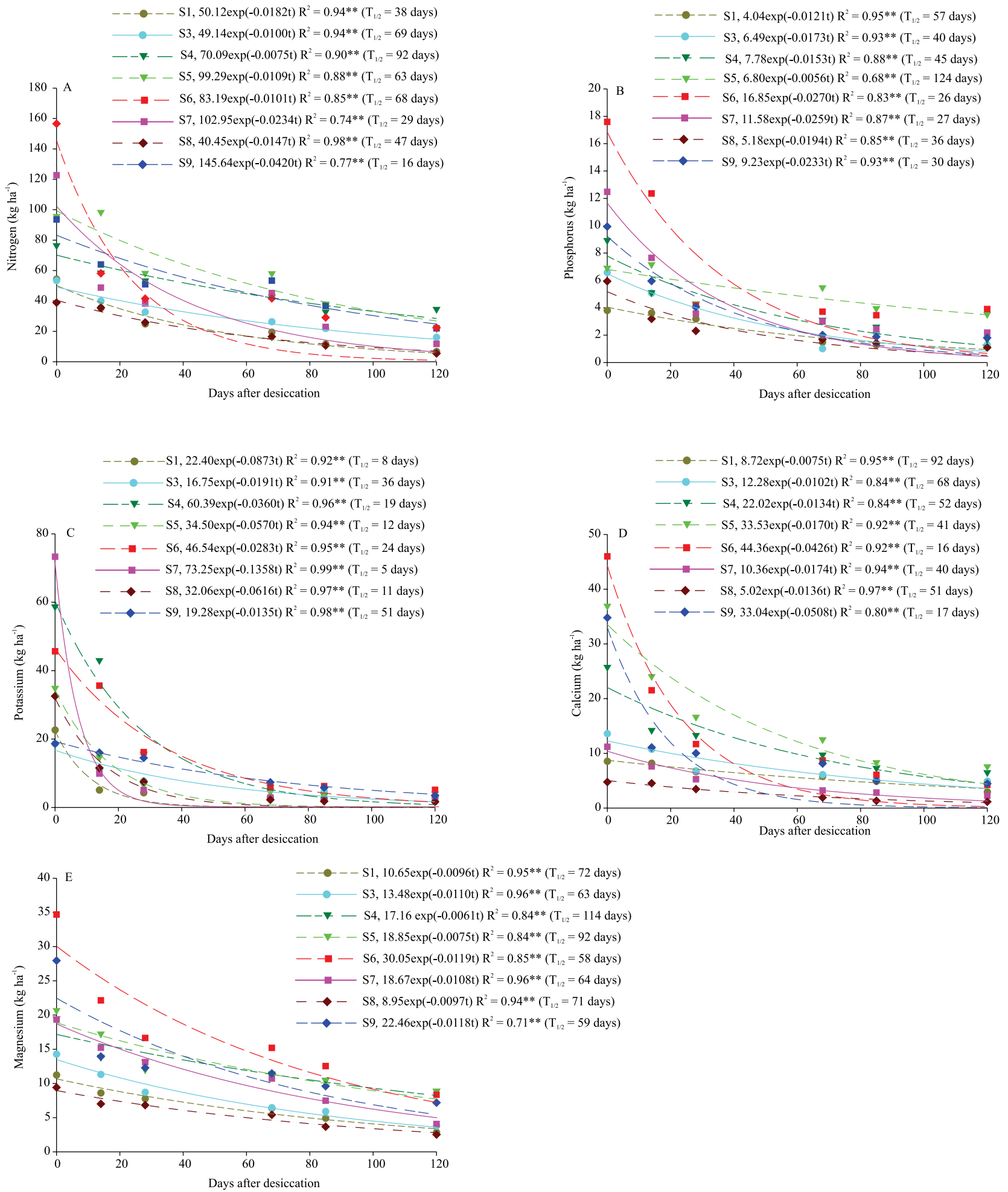

Figure 4. Release of nitrogen (A), phosphorus (B), potassium (C), calcium (D), and magnesium (E) by cover crops in the 2015/2016 crop season, in the municipality of Rondonópolis, in the state of Mato Grosso, Brazil. Cultivation systems: S1, fallow under no-tillage; S3, Crotalaria spectabilis; S4, corn (Zea mays) + Crotalaria spectabilis; S5, pearl millet (Pennisetum glaucum); S6, Urochloa ruziziensis; S7, sunflower (Helianthus annuus) + Urochloa ruziziensis; S8, cowpea (Vigna unguiculata); and S9, corn (Zea mays) + Urochloa ruziziensis. NT, no-tillage; and $\mathrm{T}_{1 / 2}$, half-life time. 

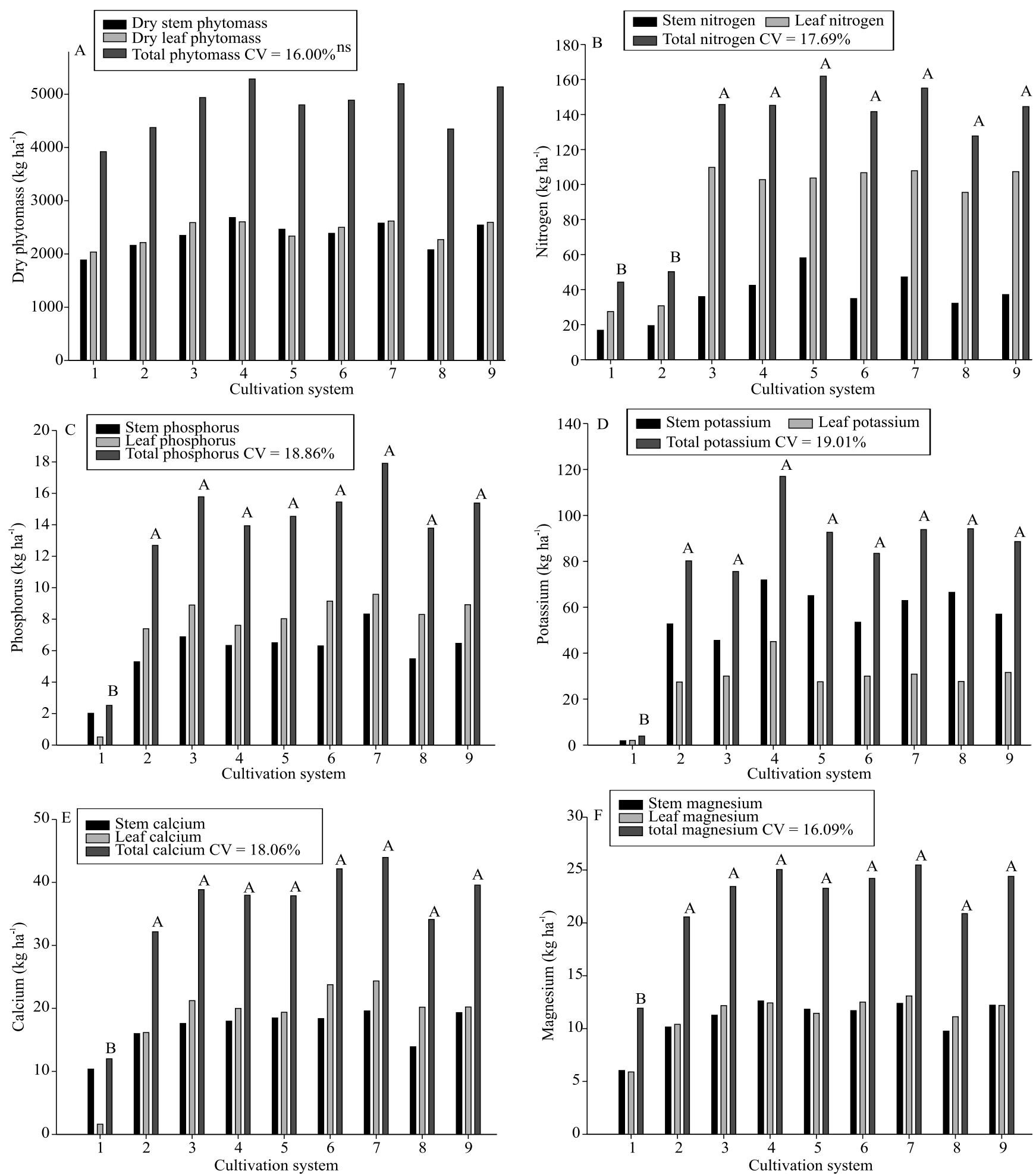

Figure 5. Phytomass production (A) and contents of nitrogen (B), phosphorus (C), potassium (D), calcium (E), and magnesium (F) during soybean (Glycine max) flowering in systems with predecessor crops and soil preparation in the municipality of Rondonópolis, in the state of Mato Grosso, Brazil, in the 2015/2016 crop season. Cultivation systems: $\mathrm{S}_{1}$, fallow under no-tillage; $\mathrm{S}_{2}$, fallow under conventional tillage; $\mathrm{S}_{3}$, Crotalaria spectabilis; $\mathrm{S}_{4}$, corn (Zea mays) + C. spectabilis; $\mathrm{S}_{5}$, pearl millet (Pennisetum glaucum); $\mathrm{S}_{6}$, Urochloa ruziziensis; $\mathrm{S}_{7}$, sunflower (Helianthus annuus) + U. ruziziensis; $\mathrm{S}_{8}$, cowpea (Vigna unguiculata); and $\mathrm{S}_{9}$, corn + U. ruziziensis. Means followed by equal letters, in the columns, do not differ by

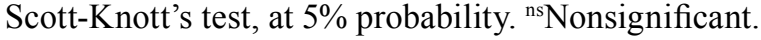


the two types of crops is attributed to unfavorable climatic conditions during the grain-filling phase in the 2015/2016 crop season, i.e., to the low rainfall in December 2015 (Figure 1), as also verified by Mataran Neto et al. (2016) in the state of Mato Grosso.

There was a cumulative effect of nutrient cycling in the cropping systems, which favored the productive potential of soybean, with greater nutrient accumulation in the plant shoot. Crotalaria spectabilis presented a slower and more gradual release of all nutrients, which took an average of 60 days after desiccation. This time was close to the phenological stage of soybean flowering (43 days after sowing) and was the period with the highest nutrient requirement by the crop, which may have contributed to the significant difference in soybean grain yield observed for this treatment. Soratto et al. (2012) found crotalaria showed a more rapid nutrient release, with a mean of 33 days for all nutrients in Botucatu, in the state of São Paulo, Brazil. It should be highlighted that $\mathrm{K}$, which, after $\mathrm{N}$, was accumulated in larger quantities in the phytomass of soybean in

Table 4. Grain yield of soybean (Glycine max) grown in succession to annual and cover crops sown in the off-season in nine cultivation systems, in the 2014/2015 and 2015/2016 crop seasons $^{(1)}$.

\begin{tabular}{|c|c|c|}
\hline \multirow[t]{2}{*}{ Farming system } & \multicolumn{2}{|c|}{$\begin{array}{l}\text { Soybean grain yield } \\
\qquad\left(\mathrm{kg} \mathrm{ha}^{-1}\right)\end{array}$} \\
\hline & $2014 / 2015$ & $2015 / 2016$ \\
\hline $\begin{array}{l}\mathrm{S}_{1} \text {, soybean - fallow under NT/ soybean - } \\
\text { fallow under NT }\end{array}$ & $2.763^{\text {ns }}$ & $1.889 \mathrm{C}$ \\
\hline $\begin{array}{l}\mathrm{S}_{2} \text {, soybean - fallow under } \mathrm{CT} / \text { soybean - } \\
\text { fallow under } \mathrm{CT}\end{array}$ & 2.837 & $2.276 \mathrm{~B}$ \\
\hline $\begin{array}{l}\mathrm{S}_{3} \text {, soybean - Crotalaria spectabilis/ } \\
\text { soybean - Crotalaria spectabilis }\end{array}$ & 4.059 & $2.686 \mathrm{~A}$ \\
\hline $\begin{array}{l}\mathrm{S}_{4} \text {, soybean - Crotalaria brevifloral } \\
\text { soybean - corn (Zea mays) + Crotalaria } \\
\text { spectabilis }\end{array}$ & 4.054 & $2.155 \mathrm{~B}$ \\
\hline $\begin{array}{l}\mathrm{S}_{5} \text {, soybean - pearl millet (Pennisetum } \\
\text { glaucum)/ soybean - pearl millet }\end{array}$ & 3.349 & $2.347 \mathrm{~B}$ \\
\hline $\begin{array}{l}\mathrm{S}_{6} \text {, soybean - Urochloa ruziziensis/soybean } \\
\text { - Urochloa ruziziensis }\end{array}$ & 3.373 & $2.273 \mathrm{~B}$ \\
\hline $\begin{array}{l}\mathrm{S}_{7}, \text { soybean - pigeon pea (Cajanus cajan)/ } \\
\text { soybean - sunflower (Helianthus annuus) }+ \\
\text { Urochloa ruziziensis }\end{array}$ & 3.660 & $2.301 \mathrm{~B}$ \\
\hline $\begin{array}{l}\mathrm{S}_{8}, \text { soybean }- \text { Stylosanthes capitata }+ \\
\text { Stylosanthes macrocephala/ soybean }- \\
\text { cowpea (Vigna unguiculata) }\end{array}$ & 3.170 & $2.425 \mathrm{~B}$ \\
\hline $\begin{array}{l}\mathrm{S}_{9} \text {, soybean - Urochloa brizantha/ soybean } \\
- \text { corn + Urochloa ruziziensis }\end{array}$ & 2.560 & $2.051 \mathrm{C}$ \\
\hline Coefficient of variation (\%) & 24.26 & 7.67 \\
\hline
\end{tabular}

some of the more diversified systems, such as corn + C. spectabilis, did not result in a higher productivity for these systems. The reason is that $\mathrm{K}$ is rapidly released to the soil because it is not connected to any of the structural components of the plant tissues (Marschner, 2012). Furthermore, there was no synchronism between its release by the systems and its absorption by the soybean crop, and the absorption of this nutrient by the soybean crop was lower since $\mathrm{K}$ is easily leached from plant cells due to the rains that occurred during harvest.

\section{Conclusions}

1. Urochloa ruziziensis alone or intercropped, compared with fallow, is recommended for no-tillage systems in the Cerrado, in the state of Mato Grosso, Brazil, because it promotes significant increases in phytomass production, soil cover, and nutrient cycling, which increase the grain yield of soybean (Glycine max) planted in succession.

2. Nitrogen and potassium are the most accumulated nutrients in the cover crop shoots and were released in greater quantities in the soil in the 2014/2015 and 2015/2016 crop seasons.

3. Crotalaria spectabilis, compared with $U$. ruziziensis, increases the grain yield of soybean planted in succession in the 2015/2016 crop season, under no-tillage system in the Cerrado, due to the synchronization between nitrogen release and uptake by the soybean crop.

\section{Acknowledgments}

To Coordenação de Aperfeiçoamento de Pessoal de Nível Superior (Capes), for scholarships granted to the first and third authors; to Conselho Nacional de Desenvolvimento Científico e Tecnológico (CNPq), for financial support (project number 484801/2012-0) and for productivity grants awarded to the second and fourth authors; and to Fundação Agrisus - Agricultura Sustentável, for financial support (project number 1604/15).

\section{References}

ANDRADE, C.M.S. de; ASSIS, G.M.L. de; SALES, M.F.L. Estilosantes Campo Grande: leguminosa forrageira recomendada para solos arenosos do Acre. Rio Branco: Embrapa Acre, 2010. 12p. (Embrapa Acre. Circular técnica, 55). 
CARVALHO, A.M. de; BUSTAMANTE, M.M. da C.; ALCÂNTARA, F.A. de; RESCK, I.S.; LEMOS, S. de S. Decomposição de resíduos vegetais e efeitos sobre carbono, nitrogênio e fósforo em Latossolo. Planaltina: Embrapa Cerrados, 2008. 24p. (Embrapa Cerrados. Boletim de pesquisa e desenvolvimento, 225).

CARVALHO, A.M. de; COSER, T.R.; REIN, T.A.; DANTAS, R. de A.; SILVA, R.R.; SOUZA, K.W. Manejo de plantas de cobertura na floração e na maturação fisiológica e seu efeito na produtividade do milho. Pesquisa Agropecuária Brasileira, v.50, p.551-561, 2015. DOI: 10.1590/S0100-204X2015000700005.

CASTRO, C. de; OLIVEIRA, F.A. de; VERONESI, C.O.; SALINET, L.H. Acúmulo de matéria seca, exportação e ciclagem de nutrientes pelo girassol. In: REUNIÃO NACIONAL DE PESQUISA DE GIRASSOL, 16; SIMPÓSIO NACIONAL SOBRE A CULTURA DO GIRASSOL, 4., 2005, Londrina. Anais. Londrina: Embrapa Soja, 2005. p.29-31. (Embrapa Soja. Documentos, 261).

CASTRO, G.F. de; SILVA, C.G.M.; MOREIRA, S.G.; RESENDE, A.V. de. Plantas de cobertura em sucessão ao milho para silagem em condições do Cerrado. Journal of Bioenergy and Food Science, v.4, p.37-49, 2017. DOI: 10.18067/jbfs.v4i1.130.

CHIEZA, E.D.; GUERRA, J.G.M.; ARAÚJO, E. da S.; ESPÍNDOLA, J.A.; FERNANDES, R.C. Produção e aspectos econômicos de milho consorciado com Crotalaria juncea L. em diferentes intervalos de semeadura, sob manejo orgânico. Revista Ceres, v.64, p.189-196, 2017. DOI: 10.1590/0034737x201764020012.

CLAESSEN, M.E.C. (Org.). Manual de métodos de análise de solo. 2.ed. Rio de Janeiro: Embrapa-CNPS, 1997. 212p.

CRUSCIOL, C.A.C.; COTTICA, R.L.; LIMA, E. do V.; ANDREOTTI, M.; MORO, E.; MARCON, E. Persistência de palhada e liberação de nutrientes do nabo forrageiro no plantio direto. Pesquisa Agropecuária Brasileira, v.40, p.161-168, 2005. DOI: 10.1590/S0100-204X2005000200009.

DETMANN, E.; SOUZA, M.A. de; VALADARES FILHO, S.C.; QUEIROZ, A.C. de; BERCHIELLI, T.T.; SALIBA, E. de O.S.; CABRAL, L. da S.; PINA, D. dos S.; LADEIRA, M.M.; AZEVEDO, J.A.G. (Ed.). Métodos para análise de alimentos. Visconde de Rio Branco: Suprema, 2012. 214p.

FERREIRA, D.F. Sisvar: um programa para análises e ensino de estatística. Revista Científica Symposium, v.6, p.36-41, 2008.

MARSCHNER, P. Marschner's mineral nutrition of higher plants. $3^{\text {rd }}$ ed. Amsterdam: Academic Press, 2012. 672p. DOI: 10.1016/C2009-0-63043-9.

MATARAN NETO, J.M.; FERREIRA, J.O.; SANTOS, J.L.S.; SILVA, A.C.; ABUD, L.L.S.; RODRIGUES, L.C. Custos da produção de milho no estado de Mato Grosso, safras 2013/14 a 2015/16. Revista Eletrônica Interdisciplinar, v.1, p.180-183, 2016.

MENDONÇA, V.Z. de; MELLO, L.M.M. de; ANDREOTTI, M.; PARIZ, C.M.; YANO, É.H.; PEREIRA, F.C.B.L. Liberação de nutrientes da palhada de forrageiras consorciadas com milho e sucessão com soja. Revista Brasileira de Ciência do Solo, v.39, p.183-193, 2015. DOI: 10.1590/01000683rbcs20150666.
NOGUEIRA, A.R. de A.; CARMO, C.A.F.S.; MACHADO, P.L.O.A. Tecido vegetal. In: NOGUEIRA, A.R. de A.; SOUZA, G.B. de (Ed.). Manual de laboratórios: solo, água, nutrição vegetal, nutrição animal e alimentos. São Carlos: Embrapa Pecuária Sudeste, 2005. p.145-199.

PACHECO, L.P.; BARBOSA, J.M.; LEANDRO, W.M.; MACHADO, P.L.O. de A.; ASSIS, R.L. de; MADARI, B.E.; PETTER, F.A. Produção e ciclagem de nutrientes por plantas de cobertura nas culturas de arroz de terras altas e de soja. Revista Brasileira de Ciência do Solo, v.35, p.1787-1799, 2011. DOI: 10.1590/S0100-06832011000500033.

PACHECO, L.P.; MONTEIRO, M.M. de S.; PETTER, F.A.; NÓBREGA, J.C.A.; SANTOS, A.S. dos. Biomass and nutrient cycling by cover crops in Brazilian Cerrado in the state of Piaui. Revista Caatinga, v.30, p.13-23, 2017. DOI: 10.1590/1983-21252017v30n102rc.

PACHECO, L.P.; PIRES, F.R.; MONTEIRO, F.P.; PROCÓPIO, S. de O.; ASSIS, R.L. de; CARMO, M.L. do; PETTER, F.A. Desempenho de plantas de cobertura em sobressemeadura na cultura da soja. Pesquisa Agropecuária Brasileira, v.43, p.815823, 2008. DOI: 10.1590/S0100-204X2008000700005.

PAUL, E.A.; CLARK, F.E. Soil microbiology and biochemistry. San Diego: Academic Press, 1989. 275p. DOI: 10.1016/B978-0-12546805-3.50004-7.

PEREIRA, F.C.B.L.; MELLO, L.M.M. de; PARIZ, C.M.; MENDONÇA, V.Z. de; YANO, É.H.; MIRANDA, E.E.V. de; CRUSCIOL, C.A.C. Autumn maize intercropped with tropical forages: crop residues, nutriente cycling, subsequent soybean and soil quality. Revista Brasileira de Ciência do Solo, v.40, p.1-20, 2016. DOI: $10.1590 / 18069657 \mathrm{rbcs} 20150003$.

RUFINI, M.; OLIVEIRA, D.P.; TROCHMANN, A.; SOARES, B.L.; ANDRADE, M.J.B. de; MOREIRA, F.M. de S. Bradyrhizobium spp. strains in symbiosis with pigeon pea cv. Fava-Larga under greenhouse and field conditions. Revista Brasileira de Ciência do Solo, v.40, p.1-14, 2016. DOI: 10.1590/18069657rbcs20160156.

SÁ, J.C.M. de; FERREIRA, A. de O.; BRIEDIS, C.; VIEIRA, Â.M.; FIGUEIREDO, A.G. de. Extração de nutrientes e produtividade de genótipos de milho afetados por níveis de palha. Acta Scientiarum. Agronomy, v.33, p.715-722, 2011. DOI: 10.4025/actasciagron.v33i4.3979.

SANTOS, H.G. dos; JACOMINE, P.K.T.; ANJOS, L.H.C. dos; OLIVEIRA, V.A. de; LUMBRERAS, J.F.; COELHO, M.R.; ALMEIDA, J.A. de; CUNHA, T.J.F.; OLIVEIRA, J.B. de. Sistema brasileiro de classificação de solos. 4.ed. Brasília: Embrapa Solos, 2014. E-book.

SILVA, A.F. da; CARVALHO, M.A.C. de; SCHONINGER, E.L.; MONTEIRO, S.; CAIONE, G.; SANTOS, P.A. Doses de inoculante e nitrogênio na semeadura da soja em área de primeiro cultivo. Bioscience Journal, v.27, p.404-412, 2011.

SILVA, S.S. da; ANDRADE, E.M.G.; OLIVEIRA, J.P.M.; SILVA, S.S. da; SILVA, S.S. da; OLIVEIRA, J.M.; MEDEIROS, A.P. de; PIMENTA, T.A.; MACARAJÁ, P.B.; PAIVA, A.C.C. de. Cultivo do girassol com adubação convencional. Informativo Técnico do Semiárido, v.9, p.39-43, 2015. 
SORATTO, R.P.; CRUSCIOL, C.A.C.; COSTA, C.H.M. da; FERRARI NETO, J.; CASTRO, G.S.A. Produção, decomposição e ciclagem de nutrientes em resíduos de crotalária e milheto, cultivados solteiros e consorciados. Pesquisa Agropecuária Brasileira, v.47, p.1462-1470, 2012. DOI: 10.1590/S0100204X2012001000008.

SOUSA, D.M.G. de; LOBATO, E. (Ed.). Cerrado: correção do solo e adubação. 2.ed. Embrapa Informação Tecnológica; Planaltina: Embrapa Cerrados, 2004. 416p.

SOUZA, A.P. de; MOTA, L.L. da; ZAMADEI, T.; MARTIM, C.C.; ALMEIDA, F.T. de; PAULINO, J. Classificação climática e balanço hídrico climatológico no estado de Mato Grosso. Nativa, v.1, p.34-43, 2013. DOI: 10.14583/2318-7670.v01n01a07.

TEIXEIRA, C.M.; LOSS, A.; PEREIRA, M.G.; PIMENTEL, C. Decomposição e ciclagem de nutrientes dos resíduos de quatro plantas de cobertura do solo. Idesia, v.30, p.55-64, 2012. DOI: 10.4067/S0718-34292012000100007.

WIEDER, R.K.; LANG, G.E. A critique of the analytical methods used in examining decomposition data obtained from litter bags. Ecology, v.63, p.1636-1642, 1982. DOI: 10.2307/1940104.

Received on May 24, 2017 and accepted on December 20, 2017 